\title{
Can surgical adhesives may cause false positivity in follow-up positron emission tomography after lung cancer resection?
}

\author{
RIza DOĞAN ${ }^{\mathbf{1}}$ (ID) \\ Serkan UYSAL $^{1}$ (ID) \\ Ulaş KUMBASAR ${ }^{2}$ (ID) \\ Deniz KÖKSAL ${ }^{3}$ (ID) \\ Burcu ANCIN ${ }^{4}$ (ID) \\ Murat TUNCEL ${ }^{5}$ (ID)
}

${ }^{1}$ Department of Thoracic Surgery, Hacettepe University School of Medicine, Ankara, Turkey

${ }^{1}$ Hacettepe Üniversitesi Tıp Fakültesi, Gögüs Cerrahisi Anabilim Dalı, Ankara, Türkiye

${ }^{2}$ Department of Cardiothoracic Surgery, Yale University School of Medicine, New Haven, United States of America

${ }^{2}$ Yale Üniversitesi Tıp Fakültesi, Gögüs Kalp Damar Cerrahisi Anabilim Dalı, New Haven, Amerika Birleşik Devletleri

${ }^{3}$ Department of Chest Diseases, Hacettepe University School of Medicine, Ankara, Turkey

${ }^{3}$ Hacettepe Üniversitesi Tıp Fakültesi, Göğüs Hastalıkları Anabilim Dalı, Ankara, Türkiye

${ }^{4}$ Department of Thoracic Surgery, Burdur State Hospital, Ankara, Turkey

${ }^{4}$ Burdur Devlet Hastanesi, Gögüs Cerrahisi Anabilim Dalı, Ankara, Türkiye

${ }^{5}$ Department of Nuclear Medicine, Hacettepe University School of Medicine, Ankara, Turkey

${ }^{5}$ Hacettepe Üniversitesi Tıp Fakültesi, Nükleer Tıp Anabilim Dalı, Ankara, Türkiye
Cite this article as: Doğan $R$, Uysal $S$, Kumbasar U, Köksal D, Ancın B, Tuncel M. Can surgical adhesives may cause false positivity in follow-up positron emission tomography after lung cancer resection? Tuberk Toraks 2021;69(1):59-64.

\section{Yazışma Adresi (Address for Correspondence)}

\section{Dr. Serkan UYSAL}

Hacettepe Üniversitesi Tıp Fakültesi,

Göğüs Cerrahisi Anabilim Dalı,

ANKARA - TÜRKIYE

e-mail: serkan.uysal@hacettepe.edu.tr

\footnotetext{
CCopyright 2021 by Tuberculosis and Thorax.
}

Available on-line at www.tuberktoraks.org.com

\section{ABSTRACT}

Can surgical adhesives may cause false positivity in follow-up positron emission tomography after lung cancer resection?

Introduction: Postoperative complications following thoracic procedures are a major cause of morbidity and mortality. Alveolar air leaks and/or bronchopleural fistulas are associated with increased risk of infection, prolonged chest tube, and hospital stay duration and therefore generate economical concern for health care providers. A variety of surgical sealants or adhesives have been introduced to overcome this complication. Since intraoperative BioGlue ${ }^{\circledast}$ application can also cause an inflammatory reaction and mimic tumor recurrence on FDG PET-CT, in the present study we aimed to investigate its potential role in false-positive PET-CT results in patients operated for NSCLC.

Materials and Methods: Data of six patients who underwent resection for primary NSCLC at our institution (Department of Thoracic Surgery, Hacettepe University Medical Faculty) between January 2015 and December 2018 and had false positivity, due to BioGlue ${ }^{\circledast}$ application, at the bronchial stump in follow-up FDG PET-CT were retrospectively analyzed from a prospectively collected database. 
Results: One of the 6 patients was female and 5 were male. The mean age was 68 years (range, 56-79 years). The average time interval between operation and postoperative FDG-PET imaging was 4.3 months (range, 4-6 months). Follow-up FDG-PET imaging SUVmax values ranged between 3.0 and 9.0 (median: 5.33). All patients have been evaluated by FDG-PET scan following the detection of soft tissue densities at the surgical site suspicious for recurrence at their follow-up chest CT scans. Four patients underwent a bronchoscopic examination, bronchial stumps were examined and multiple biopsies were taken from suspicious nodules or tissues and sent for pathologic examination. Histopathological results revealed inflammation which is compatible with foreign body granuloma, without any suspicion for malignancy, in all cases. Two patients were solely followed-up and subsequent FDG-PET imaging after 3 months revealed complete resolution of FDG uptake.

Conclusion: To avoid unnecessary biopsies or surgical procedures, the possibility of false-positive results due to surgical adhesive product use should be taken into account while interpreting follow-up FDG-PET imaging results and the operative reports should be written in detail, describing which surgical materials used and their exact application sites.

Key words: Surgical adhesives; lung cancer; surgery; pet-ct

\section{ÖZ}

Cerrahi doku yapıştırıcılar akciğer kanseri rezeksiyonu sonrası takip pozitron emisyon tomografisinde yanlış pozitifliğe neden olur mu?

Giriş: Torasik cerrahi uygulamaları sonrasında gelişen postoperatif komplikasyonlar, morbidite ve mortalitenin önemli bir nedenidir. Alveolar hava kaçakları ve / veya bronkoplevral fistüller, artan enfeksiyon riski, göğüs tüpünün uzun süre bulunması ve uzun süre hastanede kalıs ile ilişkilidir. Bu nedenler sağlık hizmeti sağlayıcıları için ekonomik endişe yaratır. Bu komplikasyonun üstesinden gelmek için çeşitli cerrahi sızdırmazlık malzemeleri veya yapıştııııılar piyasaya sürülmüştür. İntraoperatif BioGlue ${ }^{\circledR}$ uygulaması da FDG PET-BT'de enflamatuar reaksiyona yol açıp tümör nüksünü taklit edebildiğinden, bu çalışmada KHDAK (küçük hücreli dışı akciğer kanseri) için ameliyat edilen hastalarda cerrahi doku yapıştırıcı uygulamasının yanlış pozitif PET-BT sonuçlarındaki potansiyel rolünü araştırmayı amaçladık.

Materyal ve Metod: Ocak 2015-Aralık 2018 tarihleri arasında kurumumuzda (Hacettepe Üniversitesi Tıp Fakültesi Gögüs Cerrahisi Anabilim Dalı) primer KHDAK nedeniyle rezeksiyon yapılan ve takip FDG PET-BT'de bronşiyal güdükte BioGlue ${ }^{\circledR}$ uygulaması nedeniyle yanlış pozitifliği olan altı hastanın verileri, prospektif olarak toplanan bir veri tabanından geriye dönük olarak analiz edildi.

Bulgular: 6 hastadan biri kadın, 5’i erkekti. Ortalama yaş 68 yıldı (aralık, 56-79 yaş). Operasyon ile postoperatif FDG-PET görüntüleme arasındaki ortalama süre 4,3 aydı (aralık, 4-6 ay). Takip FDG-PET görüntüleme SUVmax değerleri 3,0 ile 9,0 (medyan: 5,33) arasında değişti. Tüm hastalar, takip göğüs BT taramalarında nüks şüphesi olan cerrahi bölgede yumuşak doku yoğunluklarının saptanmasının ardından FDG-PET taraması ile değerlendirildi. Dört hastaya bronkoskopik inceleme yapıldı, bronşiyal güdükler incelendi ve şüpheli nodül veya dokulardan çok sayıda biyopsi alınarak patolojik incelemeye gönderildi. Histopatolojik sonuçlar, tüm olgularda malignite şüphesi olmaksızın yabancı cisim granülomu ile uyumlu inflamasyonu ortaya çıkardı. Iki hasta sadece takip edildi ve 3 ay sonra FDG-PET görüntülemesi FDG alımının tamamen çözüldüğünü gösterdi.

Sonuç: Gereksiz biyopsilerden veya cerrahi işlemlerden kaçınmak için, takip FDG-PET görüntüleme sonuçları yorumlanırken cerrahi yapışırıı ürün kullanımına bağlı yanlış pozitif sonuç olasılığı göz önünde bulundurulmalı ve ameliyat raporları ayrıntılı olarak hangi cerrahi materyaller açıklanarak yazılmalıdır.

Anahtar kelimeler: Cerrahi doku yapıştırıcılar; akciğer kanseri; cerrahi; pet-bt

\section{INTRODUCTION}

Postoperative complications following thoracic procedures are a major cause of morbidity and mortality. Patients undergoing pulmonary resection for nonsmall-cell lung cancer (NSCLC) are usually elderly, smoker, have poor nutritional status and associated comorbidities, and thus have a greater risk of developing pulmonary complications (1). Amongst these complications, Alveolar air leaks and/or bronchopleural fistulas are associated with increased risk of infection, prolonged chest tube, and hospital stay duration and therefore generate economical concern for health care providers $(2,3)$. In recent years, a variety of surgical sealants or adhesives have been intro- duced to overcome this complication (4-7). BioGlue ${ }^{\circledR}$ (CryoLife International Inc., Kennesaw, GA, USA) is one of these adhesives and applied in a variety of surgical specialties including thoracic surgery. It is a synthetic material composed of purified bovine serum albumin (BSA) and glutaraldehyde and causes an inflammatory reaction following application which ends up with granulation tissue formation $(3,8,9)$.

Recurrence of NSCLC after surgical treatment is reported to be loco-regional in nearly $30 \%$ of cases and usually presents as nodules involving the parenchymal or bronchial stump staple lines (10). Accurate detection of these recurrences is crucial regarding the 
initiation of adjuvant therapies to increase survival. Fluoro-2-deoxy-D-glucose positron emission tomography (FDG-PET)-computed tomography (CT) is a follow-up imaging tool often obtained for restaging or detection of residual/recurrent disease (11). Although it is highly sensitive for the detection of these recurrences, its specificity is limited due to the increased FDG uptake caused by the inflammation of the healing stumps during the postoperative period $(12,13)$. Since intraoperative BioGlue ${ }^{\circledR}$ application can also cause an inflammatory reaction and mimic tumor recurrence on FDG PET-CT, in the present study we aimed to investigate its potential role in false-positive PET-CT results in patients operated for NSCLC.

\section{MATERIALS and METHODS}

Data of six patients who underwent resection for primary NSCLC at our institution (Department of Thoracic Surgery, Hacettepe University Medical Faculty) between January 2015 and December 2018 and had false positivity, due to BioGlue ${ }^{\circledR}$ application, at the bronchial stump in follow-up FDG PET-CT were retrospectively analyzed from a prospectively collected database. The study was approved by the ethical committee of Hacettepe University Medical Faculty. Patients' data were collected including the following variables: sex, age, type of resection, location of the lesion, the time interval between operation and postoperative FDG-PET imaging, post-resection FDG-PET findings, diagnostic bronchoscopy results, fine needle aspiration biopsy (FNAB) results, and overall outcome.

\section{FDG PET-CT Imaging Protocol}

\section{Patient Preparation}

The patients fasted for at least 6 hours before the injection. Images were acquired 60 minutes after an injection of approximately $370 \pm 32 \mathrm{MBq}$ of FDG. Patients were asked to void their bladders before imaging to reduce bladder activity.

\section{Imaging protocol}

All patients underwent PET-CT imaging from the skull base to the upper thigh with six to seven-bed positions (3 $\mathrm{min} / \mathrm{bed}$ ) on a PET-CT scanner. PET images were acquired in a $3 \mathrm{D}$ mode with a $128 \times 128$ matrix and a low-dose CT that was used for attenuation correction. An iterative reconstruction algorithm (two iterations, twenty-one subsets) followed by a post-re- construction smoothing Gaussian filter was used for image reconstruction.

\section{Image Review/Interpretation}

FDG PET-CT images were reviewed for areas of abnormally increased tracer uptake by an experienced nuclear medicine physician who was blinded to the findings of conventional and structural imaging. For visual analysis, FDG PET-CT uptake was considered abnormal if it was located outside the normal anatomical structures or if the intensity of uptake was greater than that in the background and could not be identified as physiological activity (4). The maximum standardized uptake value $\left(S \cup V_{\max }\right)$ of each lesion suspicious for recurrence was calculated.

The presence or absence of disease was confirmed by either histopathological examination or follow-up with imaging methods.

\section{Surgical Procedure}

BioGlue ${ }^{\circledR}$ was applied to 32 patients who had a history of incomplete fissure, advanced emphysematous parenchyma and who took neoadjuvant chemotherapy during the same period. All patients have undergone major lung resection (lobectomy) for non-smallcell lung carcinoma (NSCLC) by the same surgeon via an open thoracotomy technique. The same amount $(5 \mathrm{~mL})$ and brand of (BioGlue $\left.{ }^{\circledR}\right)$ surgical adhesive were used intraoperatively to all patients. All patients achieved R0 resection confirmed by final pathologic examination. Patients were followed up through to December 2019 (Table 1).

\section{RESULTS}

One of the 6 patients was female and 5 were male. The mean age was 68 years (range, $56-79$ years). The average time interval between operation and postoperative FDG-PET imaging was 4.3 months (range, 4-6 months). Follow-up FDG-PET imaging $\mathrm{SUV}_{\max }$ values ranged between 3.0 and 9.0 (median: 5.33) (Figure 1). All patients have been evaluated by FDGPET scan following the detection of soft tissue densities at the surgical site suspicious for recurrence at their follow-up chest CT scans.

Four patients underwent a bronchoscopic examination, bronchial stumps were examined and multiple biopsies were taken from suspicious nodules or tissues and sent for pathologic examination. Histopathological results revealed inflammation which is compatible with foreign body granuloma, 
Table 1. Patient characteristics

\begin{tabular}{|lccccc|}
\hline Age/Gender & Performed operation & cTNM & $\begin{array}{c}\text { Neoadjuvant Chemoteraphy/ } \\
\text { Radiotheraphy }\end{array}$ & Pathology & $\begin{array}{c}\text { Emphysema/ } \\
\text { Incomplet Fissure }\end{array}$ \\
\hline $69 / \mathrm{M}$ & RLL+LND & T1N0M0 & $-/-$ & Adenocarcinoma & $+/+$ \\
$56 / \mathrm{M}$ & RUL+LND & T1N0M0 & $-/-$ & Squamous carcinoma & $+/+$ \\
$79 / \mathrm{M}$ & RML+LND & T1N2M0 & $+/-$ & Adenocarcinoma & $+/+$ \\
$71 / \mathrm{F}$ & RUL+LND & T1N0M0 & $-/-$ & Adenocarcinoma & $+/+$ \\
$73 / M$ & LUL+LND & T2N2M0 & $+/-$ & Squamous carcinoma & $+/+$ \\
$63 / M$ & RUL+LND & T2N2M0 & $+/-$ & Adenocarcinoma & $+/+$ \\
\hline RLL: Right lower lobectomy, RML: Right middle lobectomy, RUL: Right upper lobectomy, LUL: Left upper lobectomy, LND: Lymph node dissection.
\end{tabular}

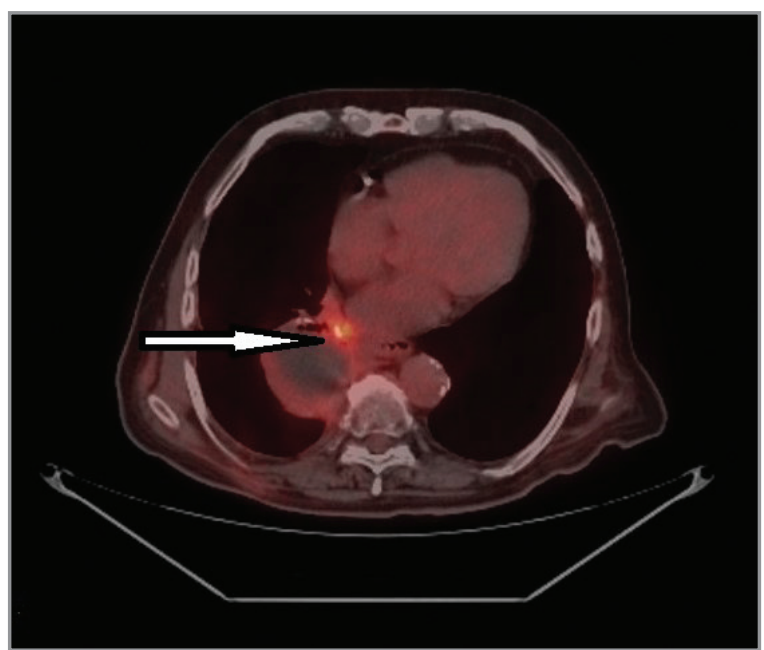

Figure 1. PET-CT image after surgery; white arrow: FDG uptake at bronchial stump.

without any suspicion for malignancy, in all cases. Two patients were solely followed-up and subsequent FDG-PET imaging after 3 months revealed complete resolution of FDG uptake. Patients' data are shown in Table 2.

\section{DISCUSSION}

Post-operative air leak from a bronchial stump is a major cause of morbidity after lung resections. It may have a detrimental effect on the postoperative course by causing bronchopleural fistulae and consequent infections which may lead to prolonged chest tube drainage and hospital stay, higher healthcare costs, and even life-threatening complication such as post-pneumonectomy empyema (14-16). Many clinicians are seeking studies that were focused on this topic to find potential methods to avoid or reduce this complication. Utilizing synthetic materials such as fibrin sealants, collagen fleece, and synthetic glues to the bronchial stump are some of the preventive methods to overcome this complication (15-18).

BioGlue ${ }^{\circledR}$, which is a synthetic material composed of purified bovine serum albumin (BSA) and glutaraldehyde, is one of these materials. It produces a stable, solid medium after these two components bind to each other and cause an inflammatory reaction which ends up with granulation tissue formation $(3,8,9,19)$. It is administered to the target area to reinforce the tissues. In all of our cases, BioGlue ${ }^{\circledR}$ was

Table 2. Patient characteristics after surgery

\begin{tabular}{|c|c|c|c|c|c|}
\hline Age/Gender & pTNM & PET interval ${ }^{\mathrm{a}}$ (month) & SUV $_{\text {max }}$-value & $\begin{array}{c}\text { Histopathologic result } \\
\text { (with FNAB) }\end{array}$ & Outcome \\
\hline $69 / M$ & T1 NOMO & 4 & 3.2 & Chronic inflammation & Alive, no recurrence \\
\hline $56 / \mathrm{M}$ & $\mathrm{T} 1 \mathrm{~N} 2 \mathrm{M} 0$ & 4 & 5.31 & Chronic inflammation & Alive, no recurrence \\
\hline $79 / \mathrm{M}$ & T1 N0M0 & 4 & 3.0 & Chronic inflammation & Alive, no recurrence \\
\hline $71 / F$ & T1 NOMO & 4 & 6.6 & Chronic inflammation & Alive, no recurrence \\
\hline $73 / \mathrm{M}$ & T2NOMO & 6 & 5.35 & NA & Alive, no recurrence \\
\hline 63/M & $\mathrm{T} 2 \mathrm{~N} 1 \mathrm{M} 0$ & 4 & 9.0 & NA & Alive, no recurrence \\
\hline
\end{tabular}


used as an adjunct to the staple lines on the bronchial stump. Following the application of BioGlue ${ }^{\circledR}$ to the target area, an inflammatory response consisting of polymorphonuclear neutrophils, macrophages and granulation tissue occurs. Granulation tissue consequently becomes fibrous scar tissue. However, in rare cases, this healing process is complicated by a chronic foreign body inflammatory reaction triggered by the synthetic material $(8,20)$.

Recurrence is a common phenomenon in the natural history of NSCLC, occurs in $20-80 \%$ of patients, and determines their survival (21). Thus, the detection of these recurrences is crucial regarding the initiation of adjuvant therapies to increase survival. The recurrence is described as loco-regional when it occurs where the primary tumor was located, at the bronchial stump, pleura, or chest wall (22).

FDG-PET is a useful follow-up imaging tool used for restaging or detection of residual/recurrent disease in patients with NCSLC. Although it is highly sensitive for the diagnosis of recurrent disease, anatomic information and the exact localization of the suspicious findings may be lacking. Besides, treatment-distorted anatomy and the increased FDG uptake caused by the inflammation of the healing stumps during the postoperative period may end up with false-positive results and hamper the correct diagnosis of recurrences (1113,23). Additionally, false-positive results have also been reported due to foreign body inflammatory reactions to surgical materials such as textile or metal elements, non-absorbable sutures, synthetic surgical adhesives, metal staples, Teflon and talc $(20,24)$. In this report, we present 6 cases who had undergone pulmonary resection for NSCLC and obtained false-positive FDG-PET results due to foreign body reactions during their follow-up period. All patients exhibited granulomatous foreign body reactions after administration of BioGlue ${ }^{\circledR}$ to their bronchial staple lines during pulmonary resection. Four out of 6 patients the inflammatory reaction was confirmed by histopathologic examination. We followed 2 patients as their follow up chest computed tomography (CT) findings were low suspicious for recurrence. Subsequently, their $S U V_{\text {max }}$ uptake values improved after 3 months. In total, we applied BioGlue ${ }^{\circledR}$ in 32 cases with variable amounts ( $5 \mathrm{cc}$ in 8 and $2 \mathrm{cc}$ in 24 cases). Although, in all cases with false PET positivity the amount of BioGlue ${ }^{\circledR}$ applied were $5 \mathrm{cc}$ it is difficult to interpret with this limited data whether the amount of glue has an impact on false positivity.

\section{CONCLUSION}

To sum up, to avoid unnecessary biopsies or surgical procedures, the possibility of false-positive results due to surgical adhesive product use should be taken into account while interpreting follow-up FDG-PET imaging results and the operative reports should be written in detail, describing which surgical materials used and their exact application sites.

Ethical Committee Approval: The approval for this study was obtained from Hacettepe University Clinical Research Ethic Committee (Decision no: 2020/05-13, Date: 25.02.2020).

\section{CONFLICT of INTEREST}

The authors of this meta-analysis declare that they have no conflict of interest.

\section{AUTHORSHIP CONTRIBUTIONS}

Concept/Design: RD

Analysis/Interpretation: SU, UK, RD, DK, MT

Data Acqusition: RD, SU, BA, UK

Writing: RD, UK, SU, MT

Clinical Revision: RD, UK, SU

Final Approval: RD

\section{REFERENCES}

1. Rock P, Rich PB. Postoperative pulmonary complications. Curr Opin Anaesthesiol 2003: 16(2): 123-31.

2. Wood DE, Lauer LM, Layton A, Tong KB. Prolonged length of stay associated with air leak following pulmonary resection has a negative impact on hospital margin. Clinicoecon Outcomes Res. 2016;8:187-95.

3. Tsilimigras DI, Antonopoulou A, Ntanasis-Stathopoulos I, Patrini D, Papagiannopoulos K, Lawrence D, et al. The role of BioGlue in thoracic surgery: a systematic review. I Thorac Dis 2017; 9(3): 568-76.

4. Anegg U, Lindenmann J, Matzi V, Smolle J, Maier A, Smolle-Juttner $F$. Efficiency of fleece-bound sealing (TachoSil) of air leaks in lung surgery: a prospective randomised trial. Eur J Cardiothorac Surg 2007; 31(2): 198202.

5. Belcher E, Dusmet M, Jordan S, Ladas G, Lim E, Goldstraw P. A prospective, randomized trial comparing BioGlue and Vivostat for the control of alveolar air leak. J Thorac Cardiovasc Surg 2010; 140(1): 32-8.

6. Dango $S$, Lin R, Hennings E, Passlick B. Initial experience with a synthetic sealant PleuraSeal after pulmonary resections: a prospective study with retrospective case matched controls. J Cardiothorac Surg 2010;5:50. 
7. Petter-Puchner AH, Simunek M, Redl H, Puchner KU, Van Griensven M. A comparison of a cyanoacrylate [corrected] glue (Glubran) vs. fibrin sealant (Tisseel) in experimental models of partial pulmonary resection and lung incision [corrected] in rabbits. J Invest Surg 2010; 23(1): 40-7.

8. Herget GW, Kassa M, Riede UN, Lu Y, Brethner L, Hasse J. Experimental use of an albumin-g/utaraldehyde tissue adhesive for sealing pulmonary parenchyma and bronchial anastomoses. Eur I Cardiothorac Surg 2001; 19(1): 4-9.

9. Tansley P, Al-Mulhim F, Lim E, Ladas G, Goldstraw P. A prospective, randomized, controlled trial of the effectiveness of BioGlue in treating alveolar air leaks. J Thorac Cardiovasc Surg 2006; 132(1): 105-12.

10. 1Caulo A, Mirsadraee S, Maggi F, Leccisotti L, van Beek EJ, Bonomo L. Integrated imaging of non-small cell lung cancer recurrence: CT and PET-CT findings, possible pitfalls and risk of recurrence criteria. Eur Radiol 2012; 22(3): 588-606.

11. Sudarski S, Henzler T, Schoenberg SO. Post-therapeutic positron emission tomography/computed tomography for early detection of non-small cell lung cancer recurrence. Transl Lung Cancer Res 2013; 2(4): 295-303.

12. Keidar Z, Haim N, Guralnik L, Wollner M, Bar-Shalom R, Ben-Nun A, et al. PET/CT using 18F-FDG in suspected lung cancer recurrence: diagnostic value and impact on patient management. I Nucl Med 2004; 45(10): 1640-6.

13. Inoue T, Kim EE, Komaki R, Wong FC, Bassa P, Wong WH, et al. Detecting recurrent or residual lung cancer with FDG-PET. J NuCl Med 1995; 36(5): 788-93.

14. Belboul A, Dernevik L, Aljassim O, Skrbic B, Radberg G, Roberts D. The effect of autologous fibrin sealant (Vivostat) on morbidity after pulmonary lobectomy: a prospective randomised, blinded study. Eur I Cardiothorac Surg 2004; 26(6): 1187-91.

15. Belda-Sanchis J, Serra-Mitjans M, Iglesias Sentis M, Rami R. Surgical sealant for preventing air leaks after pulmonary resections in patients with lung cancer. Cochrane Database Syst Rev 2010(1): CD003051.
16. Malapert G, Hanna HA, Pages PB, Bernard A. Surgical sealant for the prevention of prolonged air leak after lung resection: meta-analysis. Ann Thorac Surg 2010; 90(6): 1779-85.

17. Fabian T, Federico JA, Ponn RB. Fibrin glue in pulmonary resection: a prospective, randomized, blinded study. Ann Thorac Surg 2003; 75(5): 1587-92.

18. Porte HL, Jany T, Akkad R, Conti M, Gillet PA, Guidat A, et al. Randomized controlled trial of a synthetic sealant for preventing alveolar air leaks after lobectomy. Ann Thorac Surg 2001; 71(5): 1618-22.

19. Passage J, Tam R, Windsor M, O'Brien M. Bioglue: a review of the use of this new surgical adhesive in thoracic surgery. ANZ J Surg 2005; 75(5): 315-8.

20. Ruiz-Zafra J, Rodriguez-Fernandez A, Sanchez-Palencia A, Cueto A. Surgical adhesive may cause false positives in integrated positron emission tomography and computed tomography after lung cancer resection. Eur I Cardiothorac Surg 2013; 43(6): 1251-3.

21. Jimenez-Bonilla JF, Quirce R, Martinez-Rodriguez I, De Arcocha-Torres M, Carril JM, Banzo I. The Role of PET/CT molecular imaging in the diagnosis of recurrence and surveillance of patients treated for non-small cell lung cancer. Diagnostics (Basel) 2016; 6(4).

22. Varlotto JM, Medford-Davis LN, Recht A, Flickinger JC, Schaefer E, DeCamp MM. Failure rates and patterns of recurrence in patients with resected N1 non-small-cell lung cancer. Int J Radiat Oncol Biol Phys 2011; 81(2): 353-9.

23. Patz Jr EF, Lowe VJ, Hoffman JM, Paine SS, Harris LK, Goodman PC. Persistent or recurrent bronchogenic carcinoma: detection with PET and 2-[F-18]-2-deoxy-D-g/ucose. Radiology 1994; 191(2): 379-82.

24. Yuksel M, Akgul AG, Evman S, Batirel HF. Suture and stapler granulomas: a word of caution. Eur I Cardiothorac Surg 2007; 31(3): 563-5. 